\title{
Pengaruh Model Discovery Learning Berbantuan Media Audio Visual Terhadap Kompetensi Pengetahuan IPA
}

\author{
Ni Putu Sri Adnyani1* ${ }^{*}$ I.B Surya Manuaba,² DB. Kt. Ngr. Semara Putra ${ }^{3}$ \\ 123 Jurusan Pendidikan Guru Sekolah Dasar, Universitas Pendidikan Ganesha, Singaraja, Indonesia
}

\begin{abstract}
Abstrak
Penelitian ini bertujuan untuk mengetahui pengaruh yang signifikan model pembelajaran discovery learning berbantuan media audio visual terhadap kompetensi pengetahuan IPA pada siswa kelas IV Gugus VII Sayan Kecamatan Ubud Tahun ajaran 2019/2020. Jenis penelitian ini adalah penelitian eksperimen semu. Populasi

Kata Kunci:

Discovery Learning,

Kompetensi

Pengetahuan, IPA penelitian ini adalah seluruh kelas IV SD Gugus IV Kecamatan Ubud Tahun Pelajaran 2019/2020 yang berjumlah 105 siswa. Metode dalam pengumpulan data dilakukan dengan metode tes yaitu dengan tes obyektif. Data yang diperoleh dianalisis dengan menggunakan teknik analisis statistik deskriptif dan statistik inferensial yaitu uji-t. Hasil penelitian ini menunjukkan bahwa terdapat pengaruh kompetensi pengetahuan IPA antara siswa yang menggunakan model pembelajaran discovery learning berbantuan media audio visual dan siswa yang menggunakan model pembelajaran konvensional dengan $t_{\text {hitung }}=$ $26,733>t_{\text {tabel }}=2,021$ adanya pengaruh yang signifikan. Berdasarkan hasil analsis data model pembelajaran discovery learning berbantuan media audio visual berpengaruh terhadap kompetensi pengetahuan IPA. Hal ini dapat dilihat dari skor rata-rata siswa yang menggunakan model pembelajaran discovery learning berbantuan media audio visual yaitu 26,00 dan skor rata-rata siswa yang menggunakan model pembelajaran konvensional yaitu 15,58. Hasil uji-t dengan ttabel dengan $\mathrm{db}=23+23-2=44$ dengan taraf signifikansi $5 \%$ adalah 2,021. Hal ini berarti terdapat pengaruh secara signifikan model pembelajaran discovery learning berbantuan media audio visual terhadap kompetensi pengetahuan siswa. Dapat disimpulkan bahwa model pembelajaran discovery learning berbantuan media audio visual berpengaruh signifikan terhadap kompetensi pengetahuan IPA siswa kelas IV di SD Gugus IV Kecamatan Ubud Tahun Pelajaran $2019 / 2020$.
\end{abstract}

\begin{abstract}
This study aims to determine the significant effect of discovery learning models assisted by audio-visual media on the science competence of science in class IV Sayan Cluster VII Ubud students in 2019/2020 academic year. This type of research is quasi-experimental research. The population of this study was all class IV of Elementary School Group IV Ubud District 2019/2020 Academic Year, amounting to 105 students. The method of data collection is done by using the test method with an objective test. The data obtained were analyzed using descriptive statistical analysis techniques and inferential statistics, namely the t-test. The results of this study indicate that there is an influence of science knowledge competence between students who use discovery learning models assisted by audio-visual media and students who use conventional learning models with tcount $=26.733>$ ttable $=2.021$. Based on the analysis of discovery learning model data assisted by audio visual media influences the competence of science knowledge. This can be seen from the average score of students who use discovery learning models assisted by audio visual media that is 26.00 and the average score of students who use conventional learning models is 15.58 . The results of the t-test with a table with $\mathrm{db}=23+23-2=$ 44 with a significance level of $5 \%$ is 2.021 . This means that there is a significant influence on discovery learning models assisted by audio-visual media on students' knowledge competence. It can be concluded that the discovery learning model assisted by audio-visual media has a significant effect on the science competence of Grade IV students in Elementary School Cluster IV Ubud District 2019/2020 Academic Year.

\section{Keywords:}

Discovery learning, knowledge competence, science
\end{abstract}

\footnotetext{
* Corresponding author. 


\section{PENDAHULUAN}

Pendidikan merupakan salah satu sarana penting untuk meningkatan kualitas sumber daya manusia secara menyeluruh dalam menjamin keberlangsungan pembangunan suatu bangsa. Pendidikan dapat diartikan sebagai kegiatan seseorang dalam membimbing dan memimpin anak menuju ke pertumbuhan dan perkembangan secara optimal agar dapat berdiri sendiri dan bertanggung jawab. Pendidikan diharapkan mampu menciptakan manusia-manusia unggul melalui proses memanusiakan manusia sebagaimana hakekat pendidikan. Sejalan dengan pendapat Dantes (2014) bahwa Pendidikan pada hakikatnya adalah memanusiakan manusia. Pendidikan memiliki peran yang sangat penting dalam meningkatkan kualitas sumber daya manusia. Dengan adanya fenomena perkembangan teknologi dan Ilmu pengetahuan yang sangat pesat, SDM suatu Negara dituntut mampu memenuhi kompetensikompetensi yang dibutuhkan dalam rangka bersaing di tengah-tengah masyarakat dunia.

Pengembangan kurikulum mendukung tercapainya pendidikan yang sesuai dan berkualitas. Pendidikan yang sesuai dan berkualitas adalah suatu kegiatan belajar mengajar yang didukung oleh proses pembelajaran yang efektif, peserta didik cepat memahami apa yang diajarkan, pembaruan kurikulum, peningkatan kualitas guru, pengadaan sarana dan prasarana yang lengkap pada masingmasing sekolah. oleh karena itu sangat diperlukan peningkatan mutu pendidikan. Dalam meningkatkan mutu pendidikan, pemerintah telah menerapkan kurikulum 2013 yang merupakan penyempurnaan dari kurikulum tingkat satuan pendidikan (KTSP).

Kurikulum 2013 adalah kurikulum berbasis kompetensi. Di dalamnya dirumuskan secara terpadu kompetensi sikap, pengetahuan dan keterampilan yang harus dikuasi peserta didik. Pendidikan berdasarkan kurikulum berbasis kompetensi dirancang untuk memberikan pengalaman belajar seluasluasnya bagi peserta didik dalam mengembangkan kemampuan untuk bersikap, berpengetahuan, berketerampilan dan bertindak. Kurikulum di Indonesia harus dapat meningkatkan kompetensi pengetahuan dari setiap perserta didik.

Kompetensi pengetahuan bertujuan untuk mengukur kemampuan siswa yang bersifat kognitif Kosasih (2014). Kompetensi pengetahuan dilakukan untuk mengetahui potensi intelektual yang terdiri atas kemampuan mengingat, memahami, menerapkan, menganalisis, mengevaluasi dan mengkreasi. Seorang pendidik perlu melakukan peskoran untuk mengetahui pencapaian kompetensi pengetahuan peserta didik. Kegiatan peskoran pengetahuan tersebut dapat digunakan sebagai pemetaan kesulitan belajar peserta didik dan perbaikan proses pembelajaran. Proses pencapaiannya melalui pembelajaran sejumlah mata pelajaran yang dirangkaisebagai suatu kesatuan yang saling mendukung mencapai kompetensi tersebut salah satu mata pelajaran IPA.

Ilmu Pengetahuan alam (IPA) merupakan salah satu cabang ilmu dalam pendidikan. Menurut Susanto (2013) menyatakan bahwa Sains atau IPA adalah suatu usaha manusia dalam memahami alam semesta melalui pengamatan yang tepat pada sasaran serta menggunakan prosedur dan dijelaskan dengan penalaran sehingga mendapatkan suatu kesimpulan. IPA bukan hanya penguasaan kumpulan pengetahuan yang berupa fakta-fakta, konsep-konsep, atau prinsip-prinsip saja tetapi juga merupakan suatu proses penemuan. Susanto (2013) menyatakan bahwa pendidikan IPA diharapkan menjadi wahana bagi peserta didik untuk mempelajari diri sendiri dan alam sekitar, serta prospek pengembangan lebih lanjut dalam menerapkannya di dalam kehidupan sehari-hari.

Salah satu disiplin ilmu tersebut adalah IPA. Melalui pembelajaran IPA, siswa diharapkan dapat meningkatkan kemampuan menyesuaikan diri dengan perubahan dan memasuki dunia teknologi, termasuk teknologi informasi. Pembelajaran IPA mengarahkan siswa untuk mencapai beberapa kompetensi yang berkenaan dengan IPA itu sendiri, yakni IPA sebagai produk, proses, dan sikap. Pencapaian tiga kompetensi pokok IPA secara klasikal dapat ditinjau dari hasil belajar IPA siswa. Dengan kata lain, keberhasilan pembelajaran IPA dapat ditinjau dari kompetensi pengetahuan IPA yang diperoleh oleh siswa. Untuk mewujudkan pembelajaran IPA yang diharapan, tidaklah mudah. Pada kenyataan di sekolah masih ditemui kompetensi pengetahuan IPA siswa yang cenderung rendah. Ini yang menyebabkan Peskoran Tengah Semester siswa di bawah Kriteria Ketuntasan Minimal (KKM) yaitu 70.

Berdasarkan pemaparan data diatas, dapat dilihat bahwa kompetensi pengetahuan IPA siswa kelas IV di Gugus VII Sayan dibawah Kriteria Ketuntasan Minimal. Pembelajran IPA belum terwujud sebagaimana yang diharapkan, sehingga hasil yang dicapai belum maksimal. Sebagai sebuah variabel yang utuh, kompetensi pengetahuan sebenarnya dapat dipengaruhi oleh dua faktor yakni internal dan eksternal. Faktor eksternal berkaitan dengan segala yang berkenaan hal-hal yang berada di luar diri siswa, seperti faktor guru, kondisi kelas, maupun alat penunjang proses pembelajaran, sedangkan internal adalah hal-hal yang berada di dalam diri siswa, seperti kesehatan, motivasi dan kecerdasan. Faktor yang dirasa lebih dominan adalah faktor internal dari peserta didik. Salah satu faktor internal yang dapat mempengaruhi kompetensi pengetahuan siswa adalah tingkat kemampuan pengetahuan siswa. 
Untuk mengatasi permasalahan tersebut, diperlukan inovasi dari guru untuk mengemas pembelajaran IPA secara optimal. Perlu diketahui bahwa dengan mengguakan model Discovery Learning dapat lebih meningkatkan kompetensi pengetahuan siswa dalam mengikuti pembelajaran dikelas. Pada saat mengikuti proses pembelajaran, inovasi yang kreatif sangat diperlukan agar siswa bisa mengikuti proses belajar dengan baik. salah satunya inovasi model pembelajaran yang dapat digunakan agar siswa dapat ikut terlibat aktif dalam proses pembelajaran sehingga berdampak pada peningkatan kompetensi pengetahuan siswa dikelas IV SD di gugus VII Sayan Kecamatan Ubud dengan menggunakan model discovery learning.

Model Discovery Learningmenurut Ausubel dalam Marhaeni (2013) mengatakan bahwa discovery learning merupakan cara belajar penemuan. Siswa diarahkan untuk menemukan pengetahuannya sendiri terkait dengan materi yang dipelajari sehingga belajar menjadi lebih bermakna. Bruner dalam Marhaeni (2013) juga menganggap bahwa belajar penemuan sesuai dengan pencarian pengetahuan secara aktif oleh manusia, dan dengan sendirinya memberi hasil yang baik. Model Discovery learning yang menekankan penemuan dirasa mampu mengembangan kompetensi pengetahuan siswa. Pembelajaran berbasis penemuan ini akan menghadirkan suasana belajar yang aktif dan bermakna bagi siswa. Untuk mengoptimalkan kebermaknaan kegiatan pembelajaran tersebut, diperlukan satu penuntun yang mampu mengantarkan siswa kepada kompetensi pengetahuan siswa dalam menanggapi gejala-gejala alam yang terjadi di sekelilingnya. Dengan memanfaatkan media audio visual model discovery learning diduga dapat mengasah pengetahuan siswa lebih efektif dan bermakna.

Menurut Arsyad (2016) media audio visual adalah media yang digunakan dalam kegiatan pembelajaran dengan melibatkan pendengaran dan penglihatan sekaligus dalam suatu kegiatan atau proses. Pesan dan informasi yang dapat disalurkan melalui media ini dapat berupa pesan verbal dan nonverbal yang mengandalkan baik penglihatan maupun pendengaran.

Model discovery learning berbantuan media audio visual adalah model pembelajaran yang lebih menekankan pentingnya penguasaan pelajaran yang melibatkan pendengaran dan penglihatan sekaligus dalam suatu kegiatan atau proses, pembelajaran yang disampaikan media ini dapat berupa pesan verbal dan nonverbal yang mengandalkan baik penglihatan maupun pendengaran yang berdampak pada peningkatan kompetensi pengetahuan dari siswa khususnya dalam pembalajaran IPA (Rosarina dkk, 2016)

Maka perlu untuk melakukan kajian tentang model pembelajaran yang paling efektif dalam upaya untuk meningkatkan kompetensi pengetahuan siswa, sehingga dilakukan penelitian dengan judul Pengaruh Model Discovery Learning Berbantuan Media Audio Visual Terhadap Kompetensi Pengetahuan IPA Kelas IV Gugus VII Sayan Kecamatan Ubud Tahun Ajaran 2019/2020.

\section{METODE PENELITIAN}

Penelitian ini dilaksanakan di kelas IV SD Negeri Gugus VII Sayan yang terletak di Kecamatan Gianyar dengan melibatkan 5 Sekolah Dasar Negeri diantaranya adalah SD Negeri 1 Sayan, SD Negeri 2 Sayan, SD Negeri 3 Sayan, SD Negeri 4 Sayan, dan SD Negeri 5 Sayan. Waktu penelitian terkait dengan pelaksanaan penelitian ini yaitu pada semester II. Penelitian ini menggunakan pendekatan kuantitatif. Jenis penelitian ini adalah penelitian eksperimen semu dengan desain eksperimental (quasi experiment).Desain pada penelitian ini "memiliki kelompok kontrol, tetapi tidak dapat berfungsi sepenuhnya untuk mengontrol variabel-variabel luar yang mempengaruhi pelaksanaan eksperimen". Rancangan penelitian yang digunakan adalah desain penelitian eksperimen "non-equivalent control group design".

Secara skematis, desain eksperimen semu (quasi experimental design) yang digunakan pada penelitian ini dapat diilustrasikan pada Tabel 1 sebagai berikut.

Tabel 1. Desain Penelitian Non-Equivalent Post-Test Only Control Group Design (Dantes, 2012:75)

\begin{tabular}{cll}
\hline Kelas & Perlakuan & Post-test \\
\hline $\mathrm{E}$ & $\mathrm{X}_{1}$ & $\mathrm{O}_{1}$ \\
$\mathrm{~K}$ & $\mathrm{X}_{2}$ & $\mathrm{O}_{2}$ \\
\hline
\end{tabular}

\section{Keterangan:}

E : kelompok eksperimen

$\mathrm{K} \quad$ : kelompok kontrol

$\mathrm{X}_{1} \quad$ : kelompok yang mendapat perlakuan dengan model discovery learning

$\mathrm{X}_{2}$ : kelompok yang mendapat perlakuan dengan model konvensional

$\mathrm{O}_{1}$ : tes akhir (Post-test) kelompok eksperimen 
Pelaksanaan penelitian yang dilakukan dalam penelitian ini akan dijelaskan sebagai berikut yakni menentukan sekolah yang akan digunakan sebagai tempat penelitian. Sekolah yang dipilih yaitu Sekolah Dasar di Gugus VII Sayan Kecamatan Ubud. Kemudian melakukan observasi, wawancara dan pencatatan dokumen yang dibutuhkan, menentukan populasi dan sampel penelitian. Populasi penelitian adalah seluruh siswa kelas IV SD Gugus VII Sayan Kecamatan Ubud, setelah sampel sudah terpilih, diadakan pengundian untuk menentukan kelompok eksperimen dan kelompok kontrol diberikan model Discovery Learning SD N 2 Sayan terpilih menjadi kelompok eksperimen dan kontrol jadi kelas IV sebagai kelas eksperimen yang diberikan model Discovery Learning, menyusun instrumen dan menyusun RPP, dan RPP disiapkan untuk kelompok eksperimen dan control, konsultasi Instrumen dengan dosen pembimbing, kemudian melakukan uji validitas isi istrumen (uji judges), melaksanakan uji coba instrument agar layak digunakan di dalam penelitian. Istrumen diujikan pada siswa yang kelasnya lebih tinggi dari siswa kelompok eksperimen yaitu pada siswa kelas V, revisi dan perbaikan instrument, menyusun instrument penelitian yang akan digunakan sebagai post-test, memeriksa hasil post-test siswa, menganalisis hasil serta menguji hipotesis penelitian, menyusun laporan penelitian (skripsi).

Penelitian ini menggunakan satu kelas kelompok eksperimen dan satu kelas kelompok kontrol. Pelaksanaan dilakukan sebanyak 6 kali pertemuan dan 1 kali pertemuan untuk mengadakan post-test (1 kali pertemuan 2 x 35 menit). Perlakuan pada setiap kelompok membutuhkan waktu yang sama, urutan serta materi pelajaran yang sama. Perbedaannya hanya pada perlakuan yang diberikan pada masingmasing kelas.

Populasi adalah totalitas semua skor yang mungkin, hasil menghitung maupun pengukuran, kuantitatif maupun kualitatif daripada karakteristik tertentu mengenai sekumpulan objek yang lengkap dan jelas. Sudjana dalam Agung (2016)

Populasi dalam penelitian ini adalah seluruh kelas IV SD di Gugus VII Sayan tahun ajaran 2019/2020. Jumlah keseluruhan anggota populasi pada penelitian ini dapat dilihat pada Tabel 2.

Tabel 2. Data Siswa Kelas IV SD di Gugus VII Sayan

\begin{tabular}{ccccc}
\hline No & & Sekolah & Kelas & Jumlah \\
\hline $\mathbf{1}$ & SD N 1 Sayan & IV & 20 \\
$\mathbf{2}$ & SD N 2 Sayan & IV & 23 \\
$\mathbf{3}$ & SD N 3 Sayan & IV & 23 \\
$\mathbf{4}$ & SD N 4 Sayan & IV & 21 \\
$\mathbf{5}$ & SD N 5 Sayan & IV & 15 \\
\hline & & & 105 \\
\hline
\end{tabular}

Jika dari keseluruhan populasi yang ada, kemudian hanya diambil sebagian menjadi wakil populasi tersebut, maka wakil populasi tersebut dinamakan sampel. Jadi sampel merupakan bagian dari populasi yang secara langsung dikenai penelitian. Sejalan dengan ini, Sudjana dalam Agung (2016) menyatakan bahwa sampel merupakan sebagian yang diambil dari populasi.

Sebelum dilakukan penentuan sampel penelitian, dilakukan uji kesetaraan pada semua sekolah SD yang ada di gugus VII Kecamatan Sayan. Data yang digunakan dalam uji kesetaraan adalah skor ulangan tengah semester (UTS) ganjil muatan materi IPA kelas IV. Uji kesetaraan ini menggunakan uji-T. Hal ini menunjukkan bahwa skor UTS IPA kelima sekolah tersebut setara (sama).

Adapun teknik pengambilan sampel dalam penelitian adalah teknik random sampling. Semua kelas mempunyai kesempatan yang sama untuk dipilih menjadi sampel.Teknik group random sampling adalah suatu cara pengambilan sampel secara acak, di mana sampel diambil berdasarkan kelas bukan individu, setiap anggota populasi atau bagian dari populasi tersebut mempunyai kesempatan yang sama untuk dipilih sebagai sampel Soewarno dalam Agung (2014) Teknik group random sampling yang digunakan untuk menentukan kelas eksperimen dan kontrol dalam penelitian dengan cara undian.

Teknik group random sampling adalah suatu cara pengambilan sampel secara acak, dimana sampel diambil berdasarkan kelas bukan individu, setiap anggota populasi atau bagian dari populasi tersebut mempunyai kesempatan yang sama untuk dipilih sebagai sampel Agung (2014). Teknik group random sampling yang digunakan dalam menentukan kelas eksperimen dan kontrol dalam penelitian dengan cara undian. Untuk menentukan kelas eksperimen dan kontrol sebelumnya harus dilakukan uji kesetaraan terlebih dahulu untuk menentukan bahwa sekolah tersebut setara dijadikan penelitian. Setelah sekolah tersebut setara dilanjutkan dengan menentukan kelas eksperimen dan kontrol dengan cara pengundian di 
dalam sebuah tempat, dimana yang keluar pertama dijadikan sebagai kelas eksperimen dan yang keluar kedua diajadikan sebagai kelas kontrol.

Setiap instrumen penelitian melalui beberapa uji instrumen sehingga menunjukan hasil yang benar-benar valid. Tes tersebut berisikan kumpulan soal berjumlah 40 soal yang memiliki tingkatan aspek kognitif. Suatu penelitian dikatakan valid apabila hasil yang diperoleh disebabkan oleh variabel bebas yang dimanipulasi dan hasilnya dapat diberlakukan pada populasi penelitian. Oleh karena itu, untuk menyakinkan bahwa hasil eksperimen benar-benar sebagai akibat pemberian perlakuan, dilakukan pengontrolan validitas internal dan validitas eksternal.

Validitas dalam eksperimen adalah sejauh mana pemberian perlakuan variabel independen memiliki efek terhadap variabel dependen, tanpa keterlibatan variabel lain di luar variabel independen. Hal ini berarti, semakin tinggi efek pemberian perlakuan (variabel independen) terhadap perubahan variabel dependen, maka validitas eksperimen tersebut dikatakan tinggi. Efektifitas pengaruh pemberian perlakuan kepada variabel dependen, validitas juga ditentukan oleh sebeberapa jauh eksperimen tersebut bisa digeneralisasikan pada populasi lain yang berbeda subyek, tempat dan ekologinya. Menurut Setyosari (2016) validitas penelitian dapat dibedakan menjadi dua, yaitu validitas eksternal dan validitas internal.

Validitas internal adalah salah satu faktor yang mampu mempengaruhi suatu hasil penelitian. Dalam penelitian ini peneliti tidak menggunakan pre-test, karena jika memberikan pre-test untuk mengetahui kemampuan awal siswa kemungkinan hasil belajar siswa dipengaruhi karena siswa sudah pernah mendapatkan tes yang sama, atau yang sering disebut dengan faktor sejarah. Kemungkinan siswa mampu mendapatkan skor yang tinggi karena siswa sudah pernah menjawab soal-soal yang diberikan sebelumnya, bukan karena perlakuan yang diberikan pada saat dilakukannya eksperimen. Maka dari itu penelitian ini menggunakan data awal yaitu skor UTS IPA siswa karena skor PTS diyakini sudah mewakili kesetaran dari siswa, karena setiap gugus memiliki soal PTS yang sama.

Cara mengontrol validitas eksternal yaitu dengan melaksanakan uji kesetaraan untuk mengetahui kesetaraan populasi dalam penelitian. Berdasarkan analisis yang dilaksanakaan menggunkan teknik uj-T dengan skor hasil skor UTS IPA siswa yaag ada di Gugus VII Sayan Kecamatan Ubud. Pada taraf signifikansi hasil ulangan tengah semester pada muatan materi IPA siswa kelas IV SD Gugus VII Sayan Kecamatan Ubud, Kabupaten Gianyar dapat dinyatakan setara.

\section{ANALISIS DAN PEMBAHASAN}

Data yang diperoleh dalam melakukan post-test dengan soal objektif pilihan ganda. Data yang diperoleh dikelompokkan menjadi kompetensi pengetahuan siswa yang dibelajarkan dengan menggunakan model pembeajaran discovery learning berbantuan medua audio visual dan kompetensi pengetahuan siswa yang dibelajarkan dengan menggunakan model pembelajaran kovensional.

Data Kompetensi Pengetahuan IPA yang diperoleh melalui post-test terhadap 23 orang siswa menunjukkan bahwa skor tertinggi adalah 28 dan skor terendah adalah 24. Data kompetensi pengetahuan IPA kelompok eksperimen. Untuk menyajikan data ke dalam tabel distribusi frekuensi, terlebih dahulu ditentukan, rentangan skor (range), banyak kelas dan panjang kelas. Maka dapat dideskripsikan modus $(\mathrm{Mo})=26,87$ median $(\mathrm{Md})=26,32$ Mean $(\mathrm{M})=26,00$. Kemudian, data kompetensi pengetahuan kelompok eksperimen disajikan ke dalam bentuk grafik poligon, seperti pada Gambar 1. Tujuan penyajian ini untuk menafsirkan sebaran data kompetensi pengetahuan IPA.

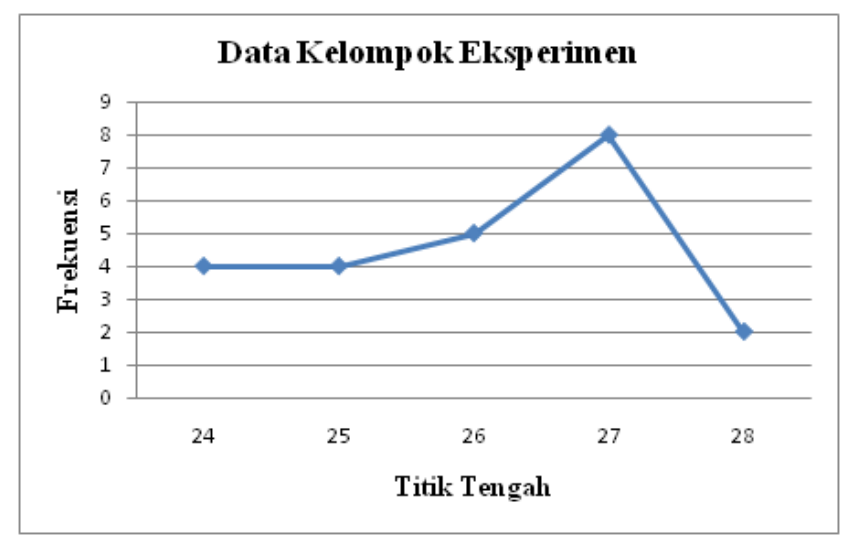

Gambar 1. Grafik Poligon Data Kompetensi Pengetahuan Kelompok Eksperimen 
Berdasarkan grafik poligon data kompetensi pengetahuan kelompok eksperimen di atas, dapat diketahui bahwa modus lebih besar dari median dan median lebih besar dari mean $(\mathrm{Mo}>\mathrm{Md}>\mathrm{M})$. Dengan kata lain, grafik di atas adalah grafik juling negatif. Artinya, sebagian besar skor cenderung tinggi. Kecenderungan skor ini dapat dibuktikan dengan melihat frekuensi relatif pada tabel distribusi frekuensi. Frekuensi relatif skor yang berada di atas rata-rata lebih besar dibandingkan frekuensi relatif skor yang berada di bawah rata-rata.

Untuk mengetahui kualitas variabel kompetensi pengetahuan pada kelas eksperimen, skor rata-rata Kompetensi Pengetahuansiswa dikonversikan menggunakan kriteria rata-rata ideal $\left(\mathrm{X}_{\mathrm{i}}\right)$ dan standar deviasi ideal $\left(\mathrm{SD}_{\mathrm{i}}\right)$ maka diperoleh hasil konversi pada Tabel 3.

Tabel 3. Hasil Skala Penilaian atau Kategori pada Skala Lima

\begin{tabular}{ll}
\hline Rentang Skor & Kategori \\
\hline $\mathbf{2 2 , 5} \leq \mathrm{X} \leq \mathbf{3 0}$ & Sangat Tinggi \\
$\mathbf{1 7 , 5} \leq \mathrm{X}<\mathbf{2 2 , 5}$ & Tinggi \\
$\mathbf{1 2 , 5} \leq \mathrm{X}<\mathbf{1 7 , 5}$ & Sedang \\
$\mathbf{7 , 5} \leq \mathrm{X}<\mathbf{1 2 , 5}$ & Rendah \\
$\mathbf{0} \leq \mathrm{X}<\mathbf{7 , 5}$ & Sangat Rendah \\
\hline
\end{tabular}

Berdasarkan hasil konversi, diperoleh bahwa skor rata-rata kompetensi pengetahuan siswa kelompok eksperimen, dengan $\mathrm{M}=26,00$ tergolong kriteria "Sangat tinggi". Data kompetensi pengetahuan IPA yang diperoleh melalui post-test terhadap 23 orang siswa menunjukkan bahwa skor tertinggi adalah 18 dan skor terendah adalah 14. Untuk menyajikan data ke dalam tabel distribusi frekuensi, terlebih dahulu ditentukan banyak kelas, rentangan skor (range), dan panjang kelas interval. Maka dapat dideskripsikan modus $(\mathrm{Mo})=15,1$ median $(\mathrm{Md})=15,57$ Mean $(\mathrm{M})=15,78$. Kemudian, data kompetensi pengetahuan kelompok kontrol disajikan ke dalam bentuk grafik poligon, seperti pada Gambar 2. Tujuan penyajian ini untuk menafsirkan sebaran data kompetensi pengetahuan IPS.

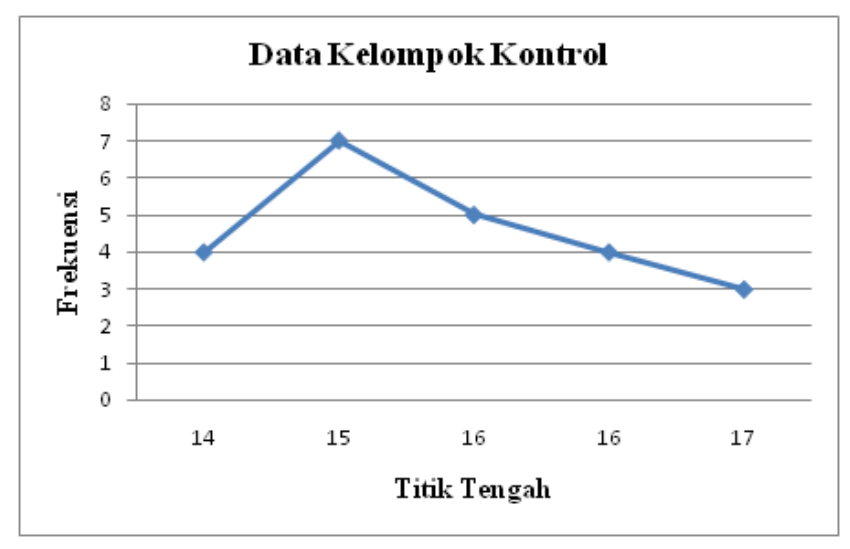

Gambar 2. Grafik Poligon Data Kompetensi Pengetahuan Kelompok Kontrol

Berdasarkan Grafik poligon data kompetensi pengetahuan kelompok kontrol di atas, dapat diketahui bahwa modus lebih kecil dari median dan median lebih kecil dari mean $(\mathrm{Mo}<\mathrm{Md}<\mathrm{M})$. Dengan kata lain, grafik di atas adalah grafik juling positif. Artinya, sebagian besar skor cenderung rendah. Kecenderungan skor ini dapat dibuktikan dengan melihat frekuensi relatif pada tabel distribusi frekuensi. Frekuensi relatif skor yang berada di atas rata-rata lebih kecil dibandingkan frekuensi relatif skor yang berada di bawah rata-rata. Selanjutnya, rata-rata skor kompetensi pengetahuan IPA siswa kelompok kontrol dikonversi kedalam kategori skala lima untuk menentukan klasifikasi skor kompetensi pengetahuan IPA siswa. Berdasarkan penghitungan yang dilakukan dengan mengikuti kategori skala lima diperoleh rata-rata skor kompetensi pengetahuan IPA kelompok kontrol adalah 15,78. Untuk mengetahui kualitas variabel kompetensi pengetahuan pada kelas eksperimen, skor rata-rata Kompetensi Pengetahuansiswa dikonversikan menggunakan kriteria rata-rata ideal $\left(\mathrm{X}_{\mathrm{i}}\right)$ dan standar deviasi ideal $\left(\mathrm{SD}_{\mathrm{i}}\right)$ maka diperoleh hasil konversi pada Tabel 4. 
Tabel 4. Hasil Skala Penilaian atau Kategori pada Skala Lima

\begin{tabular}{ll}
\hline Rentang Skor & Kategori \\
\hline $22,5 \leq \mathrm{X} \leq 30$ & Sangat Tinggi \\
$17,5 \leq \mathrm{X}<22,5$ & Tinggi \\
$12,5 \leq \mathrm{X}<17,5$ & Sedang \\
$7,5 \leq \mathrm{X}<12,5$ & Rendah \\
$0 \leq \mathrm{X}<7,5$ & Sangat Rendah \\
\hline
\end{tabular}

Berdasarkan hasil konversi, diperoleh bahwa skor rata-rata kompetensi pengetahuan siswa kelompok eksperimen, dengan $\mathrm{M}=15,78$ tergolong kriteria "Sedang".

Selanjutnya dari data yang diperoleh tersebut harus dilakukan uji normalitas data dan uji homogenitas terlabih dahulu sebelum dilanjutkan ke uji hipotesis. Syarat agara dapat dilanjutkan uji hipotesis adalah data hasrus berdiatribusi normal dan berasal dari dari varinas yang homogen. Uji normalitas sebaran data dilakukan untuk mengetahui apakah data yang diperoleh berdistribusi normal atau tidak. Jika berdistribusi normal maka uji hipotesis dapat dilakukan. Uji normalitas dalam penelitian ini menggunakan rumus Chi-Kuadrat. Dapat dilihat pada Tabel 5.

Tabel 5. Rekapitulasi Hasil Uji Normalitas Sebaran data kelompok Eksperimen dan Kontrol

\begin{tabular}{|c|c|c|c|c|}
\hline No & Data Kompetensi Pengetahuan IPA & $\mathbf{x}^{2}$ hitun & $\mathbf{X}^{2}$ tabel & Status \\
\hline 1 & Post-test Kelas Eksperimen & 3,847 & 5,591 & Normal \\
\hline 2 & Post-test Kelas Kontrol & 2,199 & 5,591 & Normal \\
\hline
\end{tabular}

Berdasarkan Tabel diatas, diketahui $\mathrm{x}^{2}$ hitung pada kelompok ekperimen adalah 3,847 dan kelompok kontrol 2,199 dengan pembanding $x^{2}$ tabel dengan taraf signifikansi 5\% adalah 5,591. Dengan kriteria pengujian jika $\mathrm{x}^{2}$ hitung $>\mathrm{x}^{2}$ tabel maka sebaran data tidak berdistribusi normal dan jika jika $\mathrm{x}^{2}$ hitung $<\mathrm{x}^{2}$ tabel maka sebaran data berdistribusi normal. Berdasarkan kriteria tersebut berarti sebaran data untuk kelompok ekperimen dan kontrol berdistribusi normal.

Uji homogenitas dilakukan untuk menunjukan bahwa perbedaan yang terjadi pada uji hipotesis benar-benar terjadi akibat adanya perbedaan varians antar kelompok, bukan sebagai akibat perbedaan dalam kelompok. Uji homogenitas dapat dilakukan apabila kelompok data tersebut berdistribusi normal. Uji homogenitas varians dilakukan dengan uji $F$. Kriteria pengujian, jika $F_{\text {hitung }}>F_{\text {tabel }}$ maka sampel tidak homogen dan jika $F_{\text {hitung }}<\mathrm{F}_{\text {tabel }}$ maka sampel homogen. Pengujian dilakukan dengan taraf signikansi 5\% dengan derajat kebebasan untuk pembilang $V_{1}=n_{1}-1$ dan derajat kebebasan untuk penyebut $V_{2}=n_{2}-1$. Rekapitulasi hasil uji homogenitas varians antar kelompok eksperimen dan kontrol disajikan pada Tabel 6 di bawah ini.

Tabel 6. Rekapitulasi Hasil Uji Homogenitas Varians

\begin{tabular}{cccc}
\hline Data & $\mathbf{F}_{\text {hitung }}$ & $\mathbf{F}_{\text {tabel }}$ & Kesimpulan \\
\hline Post-test Kelompok Eksperimen dan Kelompok Kontrol & 0,95 & 2,07 & Homogen \\
\hline
\end{tabular}

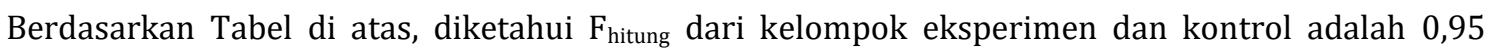
sedangkan pembanding $\mathrm{F}_{\text {tabel }}$ dengan taraf signifikansi $5 \%$ adalah 2,07. Dengan kriteria pengujian jika $\mathrm{F}_{\text {hitung }}>\mathrm{F}_{\text {tabel }}$ maka sampel tidak homogen dan jika $\mathrm{F}_{\text {hitung }}<\mathrm{F}_{\text {tabel }}$ maka sampel homogen. Berdasarkan kriteria pengujian tersebut bahwa sebaran data untuk uji hmogenitas pada kelompok ekperimen dan kontrol adalah homogen.

Kriteria pengujian jika, maka $\mathrm{H}_{0}$ ditolak dan $\mathrm{H}_{1}$ diterima. ini berarti terdapat perbedaan yang signifikan. Tetapi jika, maka $\mathrm{H}_{0}$ diterima dan $\mathrm{H}_{1}$ ditolak. Ini berarti tidak terdapat perbedan yang signifikan. Pengujian dilakukan dengan taraf signifikansi 5\% dengan derajat kebebasan db $=\mathrm{n} 1+\mathrm{n} 2-2$. Rangkuman hasil analisis uji-t ditampilkan pada Tabel 7 berikut. 
Tabel 7. Rekapitulasi Hasil Uji-T

\begin{tabular}{|c|c|c|c|c|c|}
\hline Kelompok & $\mathrm{N}$ & $\mathrm{Db}$ & Mean & $t_{\text {hitung }}$ & $t_{\text {tabel }}$ \\
\hline Eksperimen & 23 & \multirow{2}{*}{44} & 26,00 & \multirow{2}{*}{26,733} & \multirow{2}{*}{2,021} \\
\hline Kontrol & 23 & & 15,78 & & \\
\hline
\end{tabular}

Berdasarkan Tabel analisis di atas, dapat diketahui $t_{\text {hitung }}=26,733$ dan $t_{\text {tabel }}=2,021$ untuk db $=44$ pada taraf signifikansi $5 \%$. Berdasarkan kriteria pengujian, $t_{\text {hitung }}>t_{\text {tabel }}$ maka $\mathrm{H}_{0}$ ditolak dan $\mathrm{H}_{1}$ diterima. Artinya, terdapat pengaruh yang signifikan model pembelajaran discovery learning berbantuan media audio visual terhadap kompetensi pengetahuan pada kelas IV SD Gugus VII Sayan, Kecamatan Ubud Tahun Ajaran 2019/2020.

Pada bagian ini dibahas lebih lanjut mengenai hasil penelitian yang diperoleh dari kelompok eksperimen yang menggunakan model pembelajaran discovery learning berbantuan media audio visual dan kelompok kontrol yang menggunakan model pembelajaran konvensional. Kelompok eksperimen dan kelompok kontrol diberikan perlakuan dan setelah perlakuan kedua kelompok diberikan post-test untuk mendapatkan data kompetensi pengetahuan IPA pada kelompok eksperimen dan kontrol.

Setelah menganilisis dari data post-test dari kedua kelompok belajar dapat diperoleh skor rata-rata pada kelompok eksperimen 26,00 dan kelompok kontrol 15,78. Dari hasil perhitungan bahwa diketahui bahwa data post-test kedua kelompok belajar normal dan homogen. Dari hasil analisis dengan uji-t diperoleh $t_{\text {hitung }} 26,733$. Harga tersebut dibandingkan dengan $t_{\text {tabel }}$ dengan $\mathrm{db}=23+23-2=44$ dengan taraf signifikansi 5\% adalah 2,021 maka H0 ditolak. Hal ini berarti terdapat pengaruh yang signifikan model pembelajaran discovery learning berbantuan media audio visual terhadap kompetensi pengetahuan pada kelas IV SD Gugus VII Sayan, Kecamatan Ubud Tahun Ajaran 2019/2020.

Perbedaan hasil yang signifikan terhadap kompetensi pengetahan IPA siswa yang dibelajarkan dengan model pembelajaran discovery learning. Discovery learning model yang lebih menuntut siswa melakukan percobaan, bagi anak usia Sekolah Dasar (SD) pembelajaran akan lebih menarik dengan percobaan, karena dengan percobaan siswa melakukan penemuan sendiri, tidak hanya teori yang diterima siswa namun ada kesinambungan dan pembuktian antara teori dengan fakta.

Cintia dkk (2018) menyatakan discovery learning merupakan model yang mengarahkan siswa menemukan konsepmelalui berbagai informasiatau data yang diperoleh melalui pengamatan atau percobaan.

Menurut Arsyad (2016:91) menyatakan media audio visual yang menggabungkan penggunaan suara memerlukan pekerjaan tambahan untuk memproduksinya. Salah satu perkerjaan penting yang diperlukan dalam media audio visual adalah penulisan naskah dan storyboard yang memerlukan persipan banyak, rancangan, dan penelitian. Media audio visual memberikan daya tarik tersendiri kepada siswa sehingga siswa tidak menoton mendengarkan penjelasan dari guru saja tetapi dapat melihat secara konkrit materi yang disampikan dan secara tidak langsung siswa dapat melakukan pengamatan dan pemecahan masalah secara tersendiri berdasarkan masalah yang diberikan oleh guru jika menggunakan media audio visual.

Jadi model pembelajaran discovery learning berbantuan media audio visual adalah suatu model pembelajaran yang lebih menuntut siswa secara mandiri dan aktif dalam menyelesaikan permasalahan yang diberikan oleh guru dengan berbantuan media audio visual yang berupa gambar atau suara yang dapat disampaikan siswa secara cepat dapat menjawab dari permasalahan yang diberikan berdasarkan fakta dan hasil pengamatan melalui media audio visual yang disampaikan.

Sejalan penelitian yang dilakukan oleh Widiadnyana (2013) hasil penelitian menunjukkan bahwa terdapat perbedaan pemahaman konsep IPA dan sikap ilmiah antara siswa yang belajar menggunakan model discovery learning dengan siswa yang menggunakan model pembalajaran langsung. Model discovery learning sebagai proses pembelajaran yang terjadi ketika siswa tidak disajikan informasi secara langsung tetapi siswa dituntut untuk mengorganisasikan pemahaman mengenai informasi tersebut secara mandiri.

Hasil temuan pada penelitian ini memiliki persamaan dengan penelitian sebelumnya yang relevan dan memperkuat hasil penelitian yang dilakukan (Rosarina dkk, 2016)menyimpulkan bahwa model pembelajaran discovery learning berpengaruh yang terhadap hasil belajar siswa kelas IV di SDN Gudangkopi I dan (Sari dkk, 2017) yang hasil penelitiannya menunjukkan bahwa model discovery learning berbasis lingkungan berpengaruh terhadap penguasaan kompetensi pengetahuan IPA siswa kelas VI SD Negeri Gugus Srikandi Kecamatan Denpasar Timur tahun pelajaran 2016/2017. Putrayasa dkk, (2014)menyimpulkan bahwa model pembelajaran discovery learning dan minat belajar terhadap hasil belajar IPA siswa berpengaruh terhadap hasil belajar IPA siswa. (Rudyanto, 2016) menyatakan bahwa 
model discovery learning dengan pendekatan saintifik bermuatan karakter untuk meningkatkan kemampuan berpikir kreatif berpengaruh.

Berdasarkan paparan tersebut, dapat disimpulkan bahwa model discovery learning berbantuan medi audio visual berpengaruh terhadap kompetensi pengetahuan IPA siswa kelas IV SD Gugus VII Sayan, Kecamatan Ubud Tahun Ajaran 2019/2020.

\section{KESIMPULAN}

Berdasarkan dari analisis data, diperoleh skor rata-rata kelompok eksperimen 26,00 dan kelompok kontrol 15,78. Ini menunjukkan bahwa skor rata-rata kelompok eksperimen 26,00 >15,78 dari kelompok kontrol. Berdasarkan analisis data dengan uji-t diperoleh $t_{\text {hitung }}=26,733$ sedangkan pada taraf signifikansi $5 \%$ dan $\mathrm{db}=44$ diperoleh harga $\mathrm{t}_{\text {tabel }}=2,021$. Dengan demikian, $t_{\text {hitung }}=26,733>t_{\text {tabel }}=2,021$ sehingga $\mathrm{H}_{0}$ ditolak dan $\mathrm{H}_{1}$ diterima. Ini berarti terdapat perbedaan kompetensi pengetahuan IPA antara siswa dengan model pembelajaran discovery learning berbantuan media audio visual dan siswa dengan model pembelajaran konvensional. Berdasarkan pengujian hipotesis tersebut, maka dapat disimpulkan bahwa terdapat pengaruh yang signifikan model pembelajaran discovery learning berbantuan media audio visual terhadap kompetensi pengetahuan IPA pada siswa kelas IV SD Gugus IV Sayan Kecamatan Ubud Tahun Ajaran 2018/2019. Berdasarkan penelitian yang telah dilakukan, Saran yang dapat disampaikan kepada guru, disarankan untuk menggunakan berbagai macam model pembelajaran dan media yang kreatif, khususnya dalam mata pelajaran IPA. Salah satu model pembelajaran yaitu model pembelajaran discovery learning dengan berbantuan media audio visual yang dapat meningkatkan kompetensi pengetahuan IPA siswa, kepada kepala sekolah, agar selalu mendukung penggunaan model pembelajaran yang inovatif dan kreatif dalam proses pembelajaran. Salah satunya penggunaan model pembelajaran discovery learning dengan berbantuan media audio visual sehingga siswa lebih aktif dalam proses pembelajaran, kepada peneliti lain, untuk meneruskan penelitian ini agar mampu menemukan masalah-masalah lain yang belum ditemukan, sehingga menjadi penelitian yang sempurna dari penelitian ini.

\section{DAFTAR PUSTAKA}

Agung, A.A.G. 2014. Metodologi Penelitian Pendidikan. Malang: Aditya Media Publishing.

Arsyad, Azhar. 2016. Media Pembelajaran. Jakarta: Rajawali Pers.

Arisantiani. (2017). "Pengaruh Model Pembelajaran Childrens Learning In Science (CLIS) Berbantuan Media Lingkungan Terhadap Kompetensi Pengetahuan IPA". Journal Of Educatian Technology. Volume 1 , Nomor 2.

Arya Adittia. (2017). "Penggunaan Media Pembelajaran Audio Visual Untuk Meningkatkan Hasil Belajar IPS Pada Siswa Kelas IV SD”. Jurnal Mimbar Sekolah Dasar. Volume 4. Nomor 1, (hlm 9-20)

Cintia, N. I., Kristin, F., \& Anugraheni, I. (2018). Penerapan Model Pembelajaran Discovery Learning Untuk Meningkatkan Kemampuan Berpikir Kreatif Dan Hasil Belajar Siswa. Perspektif Ilmu Pendidikan, 32(1), 69-77. https://doi.org/10.23887/jpk.v1i1.12808

Cipta Anggara. (2018). “ Pengaruh Model Pembelajaran Kooperatif Tipe TPS Berbantuan Peta Konsep Terhadap Penguasaan Kompetensi Pengetahuan IPA". International Journal of Elementary Education. Volume 2, Nomor 2.

Dantes, Nyoman. 2012. Analisis dan Desain Eksperimen. Yogyakarta: CV. Andi Offset.

Dhianti, dkk. (2017). "Pengaruh Model Dicovery Learning Terhadap Peningkatan Kemampuan Berpikir Kritis Matematika dan Self-Confidence Ditinjau Dari Kemapuan Awal Matematis Siswa". Journal JPPM. Volume 10, Nomor 2. (hlm 161-164).

Diah Adnyani. (2018). "Pengaruh Model Pembelajaran Problem Solving Berbantuan Media Audio Visual Terhadap Penguasaan Kompetensi Pengetahuan Matematika". International Journal of Elementary Education. Volume 2, Nomor 2, (hlm 94- 100) 
Dwi Handayani, Ni Made. (2017). “Model Pembelajaran Picture and Picture Berbantuan Media Audio Visual Terhadap Kompetensi Pengetahuan IPA. Journal of Education Technology. Volume 1, Nomor 3, (hlm 176-182)

Erik Rudyanto. (2016). "Model Discovery Learning Dengan Pendekatan Saintifik Bermuatan Karakter Untuk Meningkatkan Kemampuan Berpikir Kreatif. Jurnal Pendidikan Dasar Dan Pengembangan. Volume 4, Nomor 1.

Firosalia kristin. (2016). “Analisis Model Peembelajaran Discovery Learning Dalam Meningkatkan Hasil Belajar Siswa SD”. Jurnal Pendidikan Dasar PerKhasa. Volume 2, Nomor 1, (hlm 91-94)

Handayani Dewi. (2018). "Pengaruh Pendekatan Contextual Teacing And Learning Berbasis Penilaian Portofolio Terhadap Kompetensi Pengetahuan IPA". Journal For Lesson and Learning Studies. Volume 1, Nomor 3, (hlm 235-237).

Irma cintia, dkk. (2018). "Penerapan Model Pembelajaran Discovery Learning Untuk Meningkatkan Kemampuan Berpikir Kreatif Dan Hasil Belajar Siswa”. Jurnal Perspektif Ilmu Pendidikan. Vol 32. Nomor 1, (hlm 70-72).

Kosasih. 2016. Strategi Belajar dan Pembelajaran Implementasi Kurikulum 2013. Bandung: Yrama Widya.

Mia Astiti. (2017). “ Pengaruh Model Pembelajaran Children Learning In Science Berbasis Budaya Penyelidikan Terhadap Kompetensi Pengetahuan IPA". Journal Of Education Technology. Volume 1, Nomor 2.

Muhamad Kadri, Meika Rahmawati. (2015). "Pengaruh Model Pembelajaran Discovery Learning Terhadap Hasil Belajar Siswa Pada Materi Pokok Suhu dan Kalor”. Jurnal IkatanAlumni Fisika Universitas Negeri Medan. Volume 1, Nomor 1.

Novita Sari. (2017). "Pengaruh Model Pembelajaran Kooperatif Tipe NHT Berbantuan Question Cards Terhadap Kompetensi Pengetahuan IPA”. Jurnal Mimbar PGSD. Volume 5, Nomor 2, (hlm 1- 5)

Putrayasa, I. M., Syahruddin, H., \& Margunayasa, I. G. (2014). Pengaruh Model Pembelajaran Discovery Learning Dan Minat Belajar Terhadap Hasil Belajar IPA Siswa. Jurnal Mimbar PGSD Universitas Pendidikan Ganesha, 2(1), 111.

Rosarina, G., Sudin, A., \& Sujana, A. (2016). Penerapan Model Discovery Learning Untuk Meningkatkan Hasil Belajar Siswa Pada Materi Perubahan Wujud Benda. Penerapan Model Discovery Learning Untuk Meningkatkan Hasil Belajar Siswa Pada Materi Perubahan Wujud Benda, 1(1), 371-380. https://doi.org/10.17509/jpi.v1i1.3043

Rudyanto, H. E. (2016). Model Discovery Learning Dengan Pendekatan Saintifik Bermuatan Karakter Untuk Meningkatkan Kemampuan Berpikir Kreatif. Premiere Educandum : Jurnal Pendidikan Dasar Dan Pembelajaran, 4(1), 41-48. https://doi.org/10.25273/pe.v4i01.305

Rustia Dewi. (2017). “ Pengaruh Model Pembelajaran Kooperatif Tipe Two Stay Two Stray Berbantuan Media Audio Visual Terhadap Kompetensi Pengetahuan IPA Siswa Kelas V SD gugus LETDA Made Putra. Jurnal Mimbar PGSD. Volume 5, Nomor 2.

Rosdiana, dkk. (2017). "Pengaruh Pengguna Model Discovery Learning Terhadap Efektifitas dan Hasil Belajar siswa. Jurnal Teori, Penelitian dan Pengembangan. Volume 2, Nomor 8.

Sari, N. K. T. N., Suniasih, N. W., \& Wiarta, I. W. (2017). Pengaruh Model Pembelajaran Kooperatif Tipe NHT Berbantuan Question Cards Terhadap Kompetensi Pengetahuan IPA. Mimbar PGSD Undiksha, 5(2), $1-10$.

Setyosari, Punaji. 2015. Metode Penelitian Pendidikan dan Pengembangan. Jakarta: Prenadamedia Group 
Septiani , Gusrayani, Asep Kurnia Jayadinata. (2016). "Pengaruh Model Pembelajaran Discovery Learning Terhadap Ketrampilan Berpikir Kreatif Siswa PADA Materi Sifat-sifat Cahaya". Jurnal Pena Ilmiah. Volume 1, Nomor 1, (hlm 101-110).

Susanto, Ahmad. 2013. Teori Belajar dan Pembelajaran di Sekolah Dasar. Jakarta: PRENADAMEDIA GROUP.

Sulfemi, Wahyu Bagia. (2018). "Metode Role Playing Berbantuan Media Audio Visual Pendidikan Dalam Meningkatkan Belajar IPS". Jurnal Pendidikan Ilmu Pengetahuansosial Indonesia,Volume 3. Nomor 2.

Trisna. ( 2017). "Pengaruh Model Discovery Learning Terhadap Kompetensi Pengetahuan IPA Siswa Kelas VI SD Gugus Yos Sudarso Kecamatan Denpasar Selatan Tahun Pelajaran 2016/2017. Jurnal Mimbar PGSD. Volume 5, Nomor 2. (hlm 2-6).

Wahyu, Nurhasanah (2018). "Penggunaan Metode Demontrasi dan Media Audio Visual Dalam Meningkatkan Hasil Belajar Peserta Didik Mata Pelajaran IPS". Jurnal Pendas Mahakam. Volume 3 Nomor 2, (hlm 151-158),

Wahyu Bagja sulfemi, Nova Mayasari. (2019). “Peranan Model Pembelajaran Value Clarification Technique berbantuan Media Audio Visual Untuk Meningkatkan Hasil Belajar IPS. Jurnal Pendidikan. Volume 20, Nomor 1, (hlm 53-68).

Widiantini. (2017). “Model Pembelajaran Sets (Science, Environmrnt, Technology, Society) Berbantuan Virtual Lab Berpengaruh Terhadap Kompetensi Pengetahuan IPA". Journal Of Education Technology. Volume 1, Nomor 2.

Widiadnyana, dkk. (2014). "Pengaruh Model Discovery Learning Terhadap Pemahaman Konsep IPA Dan Sikap Ilmiah Siswa SMP". E-Journal Program Pascasarjana Universitas Pendidikan Ganesha. Volume 4. 